\title{
A review of e-Learning policy in school education in Singapore, Hong Kong, Taiwan, and Beijing: implications to future policy planning
}

\author{
Siu Cheung Kong • Tak-Wai Chan • \\ Ronghuai Huang • Horn Mun Cheah
}

Received: 25 April 2014/Revised: 29 June 2014/Accepted: 2 July 2014 /

Published online: 8 August 2014

(C) Beijing Normal University 2014

\begin{abstract}
The acceleration of e-Learning around the world has driven the major cities/regions in the Asia-Pacific region such as Singapore, Hong Kong, Taiwan, and Beijing to plan and implement official policies on e-Learning for enhancing the quality of school education. This article aims to review experiences and then draw lessons of these four major Asian cities/regions in the development of e-Learning policies on the dimensions of infrastructure, curriculum integration, students learning, teacher professional development, as well as leadership and capacity building. It is identified that each of the four major Asian cities/regions has its own area of emphasis in the planning of future e-Learning policies, with Singapore focusing on scaling up good practices of e-Learning among teacher community; Hong Kong focusing on creating digital classrooms supported by wireless networking for student-centered learning; Taiwan focusing on cultivating students with 21 st century skills through daily subject teaching; and Beijing focusing on providing digital resources and e-textbooks geared to school curricula. Five implications with
\end{abstract}

S. C. Kong $(\bowtie)$

Department of Mathematics and Information Technology, The Hong Kong Institute of Education, 10 Lo Ping Road, Tai Po, New Territories, Hong Kong, China

e-mail: sckong@ied.edu.hk

T.-W. Chan

Graduate Institute of Network Learning Technology, National Central University, No. 300, Jhongda Road, Jhongli City, Taoyuan County 32001, Taiwan

e-mail: chan@cl.ncu.edu.tw

\section{R. Huang}

School of Educational Technology, Beijing Normal University, 19 Xinjiekouwai Street, Haidian District, Beijing 100875, China

e-mail: huangrh@bnu.edu.cn

H. M. Cheah

President's Office, SIM University, 461 Clementi Road, Clementi, Singapore

e-mail: hmcheah@unisim.edu.sg 
regard to e-Learning policies are further made in order to provide a point of references for other cities/regions to develop future e-Learning policies for school education in the 21 st century.

Keywords E-Learning $\cdot$ Planning $\cdot$ Policy $\cdot$ School education $\cdot 21$ st century skills

\section{Introduction}

The advent of information and communication technology (ICT) in the recent decades drives the school education sector to strive for integrating ICT into curriculum delivery across different subject domains. E-Learning, which refers to the use of ICT for learning purposes, becomes an important area of emphasis in school education (Chan 2010; Condie and Munro 2007). To benefit from the process of e-Learning, students need 21st century skills to support them to select and process useful and reliable information from varying sources for learning, as well as to communicate and collaborate with their peers to complete tasks and share outcomes (Hoffman 2010; Rotherham and Willingham 2009). It is, therefore, advocated that e-Learning in school education in the coming 10 years has the learning goal of supporting students on developing both domain knowledge and 21st century skills under ICT-supported pedagogical practices in the ICT-rich learning environments (Gut 2011; Kong et al. 2014).

In the Asia-Pacific region, the major cities/regions such as Singapore, Hong Kong, Taiwan, and Beijing are putting effort into the official policies on e-Learning for enhancing the quality of school education. With different cultural backgrounds, these major Asian cities/regions have different goals and approaches in the policies on promoting e-Learning in the school education sector. This article aims to review the past policies and then discusses the future directions of e-Learning in school education among Singapore, Hong Kong, Taiwan, and Beijing.

For the systematic analysis of e-Learning policies across the four major Asian cities/regions, this article attempts to derive an analysis framework from a series of established works on the planning and implementation models of e-Learning for school education. According to Flanagan and Jacobsen (2003), Gülbahar (2007), Kong (2009), Vanderlinde et al. (2012), and Whitehead et al. (2003), schools need to be ready to enable students and teachers to sufficiently access ICT facilities and Internet connectivity on campus for the successful implementation of e-Learning activities across subjects. Kong (2009), Vanderlinde et al. (2012), and Whitehead et al. (2003) suggest that schools need to re-interpret the objectives and structures of school curricula for the meaningful integration of ICT into curriculum delivery, in order to unleash the potential of ICT on supporting subject learning and teaching. Some researchers further point out that this requires the readiness of students and teachers for ICT integration into subject learning and teaching. On the one hand, students need to be ready to learn domain knowledge and develop generic skills with the proper use of ICT (Gülbahar 2007; Kong 2009; Whitehead et al. 2003). On the other hand, teachers need to be ready to use ICT in pedagogical arrangements 
after gaining insights from teacher professional development activities on e-Learning (Flanagan and Jacobsen 2003; Gülbahar 2007; Rowan and Miller 2007; Whitehead et al. 2003). According to Flanagan and Jacobsen (2003), Rowan and Miller (2007), and Vanderlinde et al. (2012), it is important for schools to build up the campus-wide capacity for addressing these critical issues in e-Learning development, with the support from school leaders and other stakeholders on ICT in education.

The above literature review reveals the important criteria for successful e-Learning that schools should build ICT infrastructure on campus and integrate ICT elements into curriculum for supporting holistic development of student learning; and schools need the professional input from teachers, the specialized leadership from principals, and the continues support from parents on e-Learning. These criteria echo with the areas of focus for e-Learning policy as suggested by Borokhovski et al. (2011) and Erichsen and Salajan (2014). This article therefore derives an analysis framework for looking into e-Learning policies on five dimensions: "infrastructure" - the hardware, software, and Internet connectivity for e-Learning; "curriculum integration"-the re-interpretation of school curriculum and development of pedagogical practices for e-Learning; "students learning"students' development of domain knowledge and 21 st century skills through e-Learning; "teacher professional development"-teachers' pedagogical competency and training activities of e-Learning; and "leadership and capacity building"-school leadership, research support, and community involvement for e-Learning.

The following sections will first report the experiences, then discuss the lessons, and finally draw the implications with regard to e-Learning policies in school education across the four major Asian cities/regions, in line with the above fivedimension framework. It sets to provide a point of references for other cities/regions to forward the development of e-Learning policies in the 21 st century.

\section{E-Learning policy in school education in Singapore, Hong Kong, Taiwan, and Beijing in recent two decades}

As the major cities/regions in the Asia-Pacific region, Singapore, Hong Kong, Taiwan, and Beijing have continuously planned and implemented the official policies on e-Learning for enhancing the quality of school education. Table 1 shows that in each of these Asian cities/regions, there are in general three stages of e-Learning policy development over the recent two decades. This section reviews the key initiatives of e-Learning policies across these four major Asian cities/ regions.

\section{Singapore}

Since the late 1970s, Singapore has been proactive in promoting the appropriate use of technologies for day-to-day activities through six national Information 


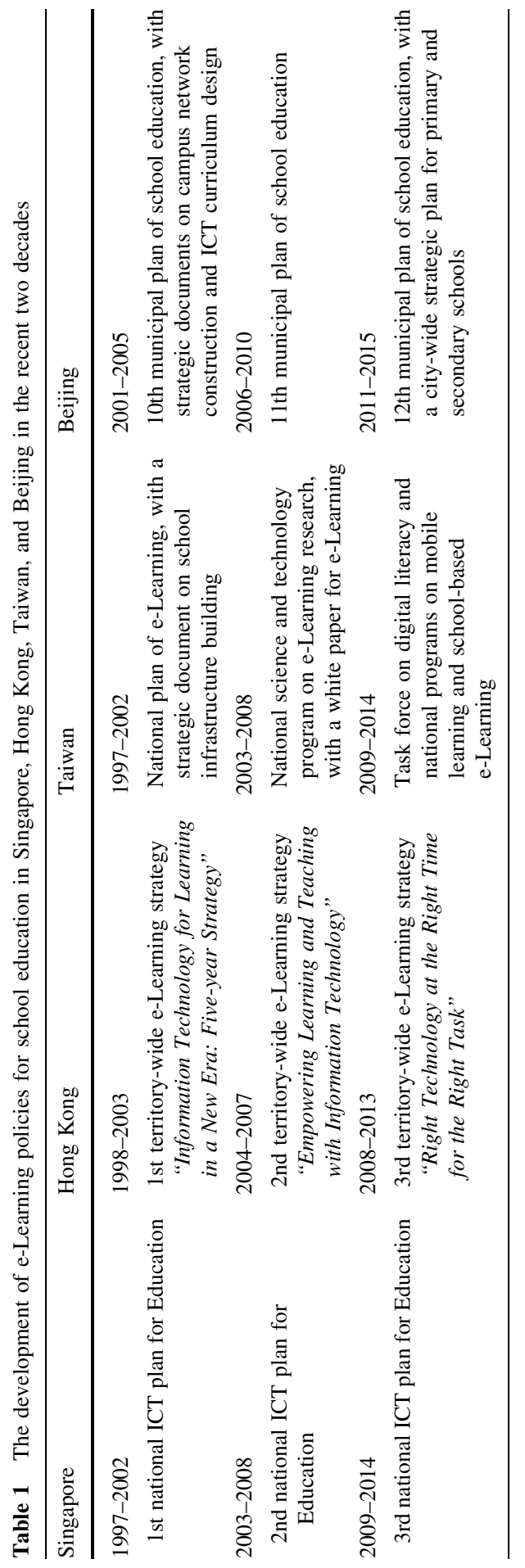


Technology (IT) plans. Within this context, the Ministry of Education embarked on three sets of ICT Masterplans for Education for all levels of schools.

\section{Stage 1: First ICT Masterplan for Education (1997-2002)}

The work of the first four National IT Plans in Singapore between 1980 and 2002 had put in place not only a physical infrastructure, but also the environment and a strong ICT-oriented mindset within the populace. Thus, when the first systemic introduction of ICT into education took the shape of the first ICT Masterplan for Education (mp1) in 1997, the education landscape in Singapore had already reached a good level of ICT maturity and largely ready for the wide-spread injection of ICT into education. Mp1 was part of an on-going national effort to use ICT for day-today activities (Ministry of Education, Singapore 1997). The implementation of mp1 attempted to bring about a pervasive and systematic use of ICT for interactions in teaching and learning, in order to level the entire system up to a point where the use of ICT was effective and pervasive (Teo 1997). Mp1 is generally characterized as a plan to build the foundation of the education system for the use of ICT in teaching and learning. This started the first stage of e-Learning promotion in Singapore from 1997 to 2002 with four major foci.

First, the Singapore government put efforts to establish ICT infrastructure on campus. It provided each school with at least two computer labs, a wired network, digital resources for teaching and learning, and ICT support. It also used system integrators to provide one-stop solutions to meet the schools' needs and the development of a repository "EduMall" for digital resources for e-Learning. Second, ICT-related curriculum was established in school education. It made a significant reduction of the school syllabus of up to $30 \%$ per subject to ensure that sufficient time was available to conduct ICT-based lessons.

Third, the Singapore government put efforts to provide technical and pedagogical training for teachers. It provided all teachers with a core ICT training through a "train-the-trainer" approach to equip all teachers with sufficient knowledge and skills for the effective use of ICT. It also provided initial teacher preparation programs and in-service training to equip teachers with core pedagogical skills in using ICT for teaching and learning, albeit somewhat limited by the availability of technologies during that period to relatively simple uses of ICT. Fourth, pilot research on e-Learning in the real classroom environment was launched. On the one hand, it encouraged "early-adopters" schools to experiment in the classrooms in a wide array of subject domains across different levels from primary to pre-university education. On the other hand, it established university-level institute to spearhead the national research and development of pedagogical aspects in e-Learning and worked with other agencies and industrial partners to explore technological innovations for e-Learning.

\section{Stage 2: Second ICT Masterplan for Education (2003-2008)}

In 2003, the Second ICT Masterplan for Education (mp2) for the period from 2003 to 2008 (Ministry of Education, Singapore 2003a) was launched. It supported the 
unleashing of the educational power of the Internet in classroom teaching and learning across school curricula, as envisioned in the fifth National IT Plan (Infocommunications Development Authority of Singapore (iDA), 2003). The vision of mp2 was the gradual build up of schools' capacity to exercise a steadily increased level of autonomy for re-shaping Learning. It did this by enhancing ICT integration into learning and teaching, promoting innovative ICT-supported pedagogies, and enhancing e-Learning readiness of schools through supporting school-based programs on e-Learning research. It encouraged schools to "seed" innovations that built on the foundation established in $\mathrm{mp} 1$. This was done by creating three tiers of schools in terms of their level of engagement in using ICT for teaching and learning. The MOE envisioned that up to $5 \%$ of schools in the country can spearhead the push for innovation in the use of ICT for education, across a system with over 360 schools, a teaching force of about 25,000, and a student population of half a million during that period (Ministry of Education, Singapore 2003b).

At the frontier of pushing innovations are schools in the Future Schools program (FS@SG), which was launched in 2007. To date, there are a total of eight Future schools. They are given additional funding to partner with industry and university researchers to push the ICT frontier in teaching and learning. Each FS@SG school has at least one project that involves the whole school. This allows for a holistic approach that can examine multi-facets of the students' learning experience in school which, in turn, positions the outcomes for system-wide scaling where appropriate. The FS@SG schools are also test-beds for the industrial partners to try out technological innovations that are applied in the teaching and learning context. The FS@SG program has produced a number of tools and applications that reach the commercialization stage; but more importantly, it has developed a strong culture in the use of ICT in the selected schools, a core group of teacher-researchers who can use research-based evidence to guide their teaching and learning practices, and an anchor point for spreading the innovative practices.

The second layer of schools, accounting for between 15 and $20 \%$ of schools, was positioned as "Lead ICT" schools. These schools also received additional funding, though at much lower levels compared to the FS@SG schools, to carry out ICT in education experimentation primarily for selected classes across education levels or for classes within the same education level. While these experimentations tended to be of smaller scale compared to those for FS@SG schools, there were few restrictions on the experimentation boundary as long as they stayed within the school curriculum and the teaching and learning context. As such, small but highly innovative practices could emerge from these Lead ICT schools.

The rest of the schools were expected to participate actively in relevant $\mathrm{mp} 2$ initiatives managed by MOE headquarter (HQ). On top of HQ-led initiatives, schools were also encouraged to develop and implement grounds-up projects conceptualized by the schools. HQ helped each school to develop its own ICT plan by providing advisory support and working closely with the school where appropriate. This enabled a more organic pursuit of the effective use of ICT for teaching and learning at the school level. 
Stage 3: Third ICT Masterplan for Education (2009-2014)

The Third ICT Masterplan for Education (mp3) was launched in 2009, covering the period up to 2014 (Ministry of Education, Singapore 2008). Mp3 is in line with the sixth National IT Plan for the period of 2006-2015, with one of its goal being to achieve $90 \%$ home broadband usage and $100 \%$ computer ownership in homes with school-going children (iDA of Singapore, undated). There are four key aspects to mp3.

First, mp3 aims to ensure that each student meets the expected achievement in ICT skills and application of ICT. This is done through establishing a set of baseline ICT standards for students. The schools can use the automated assessment tools provided for their own self-assessments.

Second, mp3 has put efforts to enhance school leadership on e-Learning through the School Leaders' professional learning program. This program adopts a peercoaching approach for influencing the community of school leaders to develop the relevant skills sets for planning and implementing school-based ICT plans. A key group of experienced principals is drawn from the FS@SG and selected Lead ICT schools to "walk" the journey of e-Learning development with principals in the program, with a focus on sharing the challenges faced, the lessons learned, and the practical advice on undertaking such a journey. This has proven to be immeasurably useful for the community of principals in the program.

Third, mp3 aims to provide on-the-ground support for teachers through the ICT mentor program. The program selects and trains four teachers per school as "ICT Mentors," who are engaged in in-depth discussions centered on the actual use of ICT in teaching and learning, making it both relevant and responsive to their teaching needs. Each ICT mentor, after successfully completing the initial foundation program, has the responsibility to mentor at least one colleague in the course of the academic year, with support from HQ and the community of ICT mentors where necessary. This achieves the effect of translating learnings into practice in a direct and meaningful manner.

Fourth, mp3 continues to focus on innovative teaching and learning practices through bringing the practices established, such as from the FS@SG program, into the system (Chen and Looi 2011).

\section{Hong Kong}

Since late 1990s, the society of Hong Kong has perceived e-Learning as an important element in the educational reform of local school education. The Hong Kong government has regarded "Information Technology for Interactive Learning" as one of the four key tasks emphasized in local curriculum development and "IT Skills" as one of the nine generic skills advocated in local curriculum reform (Curriculum Development Council 2001). In the recent decade, the Hong Kong government has invested hugely in the three stages of territory-wide promotion of e-Learning in school education, in line with the announcement of three official strategic documents on e-Learning. 
Stage 1: Information technology for learning in a New Era: five-year strategy1998/99-2002/03 (1998-2003)

In 1998-2003, the Hong Kong government implemented the first territory-wide e-Learning strategy, entitled Information Technology for Learning in a New Era: Five-year Strategy-1998/99-2002/03 (Education and Manpower Bureau 1998). The implementation of this e-Learning strategy focused on the technical factor, with initiatives mainly addressing three aspects. First, the Hong Kong governmentsupported schools on building ICT infrastructure on campus, such as the provision of desktop computers in school and the installation of campus-wide network (Education and Manpower Bureau 2005b). Second, the Hong Kong government prepared teachers for ICT integration into subject teaching. It not only set thresholds of ICT-integrated lesson time that at least $25 \%$ of teaching time involving the use of ICT, but also established baseline ICT standards for teachers according to a threelevel competency framework on teachers' teaching readiness and professional development on e-Learning (Au et al. 2000; Pun et al. 2000). Third, the Hong Kong government encouraged community involvement in e-Learning, such as parents' role in home learning with the use of ICT; tertiary institutions' development of digital learning resources; and community groups' provision of ICT facilities in community centers (Education and Manpower Bureau 2005b).

\section{Stage 2: Empowering learning and teaching with information technology} (2004-2007)

The Hong Kong government implemented the second territory-wide e-Learning strategy entitled Empowering Learning and Teaching with Information Technology from 2004 to 2007, with a focus on both technical and pedagogical factors (Education and Manpower Bureau 2004). The initiatives in this e-Learning strategy mainly addressed three aspects. First, there were efforts to develop information literacy framework for school use. The Hong Kong government collaborated with local tertiary institutions to tailor make a four-dimension framework with a set of clear learning targets related to students' information literacy. This framework aimed to guide the local school education sector to promote students' proper and ethical use of ICT in daily life, especially for learning purposes (Education and Manpower Bureau 2005a; Kong 2007, 2008). Second, there were efforts to pioneer school-based e-Learning pedagogical innovations following the advancement of ICT infrastructure on campus. For example, it established Composite Information Technology Grant (CITG) for schools to acquire devices, resources, or services related to e-Learning development in school (Education and Manpower Bureau 2007). It also supported pilot schemes on the review of existing e-Learning resources and the educational use of new ICT tools, such as Law et al. (2008), with an aim to bridge the needs of schools in curriculum delivery. Third, there were efforts to enhance training for e-Leadership in school education. The Hong Kong government provided school leaders with guidance on the goal-setting for ICT in education; organized e-Leadership training and professional sharing for school leaders; and invited renowned academics in the field of e-Leadership for public 
seminars. These measures aimed to support school leaders to build capacity for using ICT to prompt curriculum innovation (Education and Manpower Bureau 2007).

\section{Stage 3: Right technology at the right time for the right task (2008-2013)}

The Hong Kong government implemented its third territory-wide e-Learning strategy entitled Right Technology at the Right Time for the Right Task from 2008 to 2013, with a focus on the human factor (Education Bureau 2008). The initiatives in this e-Learning strategy mainly addressed three aspects. First, it put efforts to develop online depository with curriculum-based digital resources. The Hong Kong government developed a cross-subject online depository for four main subjects in primary school curriculum and 12 subjects in secondary school curriculum (Education Bureau 2012). This online depository is constructed to have a systematic content categorization by subjects, grades, and themes for facilitating users to easily search, retrieve, and share useful digital resources geared to the local curriculum needs. Second, it put efforts to develop e-textbooks for e-Learning in school education. In view of the official recommendation on localizing curriculum-based e-textbooks (Education Bureau 2009b), the Hong Kong government launched two phases of E-Textbook Market Development Scheme (EMADS) in the late 2012 and the late 2013 (Education Bureau 2012. It selected a number of educational publishers and non-profit-making organizations to develop diverse sets of e-textbooks which are self-contained curriculum packages with appropriate e-features for learning in class and at home. Third, it put efforts to support school-based planning of ICT in education. The Hong Kong government developed a four-component resource pack "School Development of IT in Education" for supporting schoolbased e-Learning planning among all types of schools in Hong Kong (Education Bureau 2009a; Kong 2009) and required all schools to develop their own schoolbased e-Learning plans for receiving a one-off grant for infrastructure procurement (Education Bureau 2012).

Taiwan

The Taiwan government has been making significant investment in the research and development on e-Learning since 1980s. With the announcement of a 10-year program on building school ICT infrastructure in 1997, Taiwan has officially started the promotion of e-Learning in school education in the recent decades with three stages.

Stage 1: National plan of e-Learning, with a strategic document on school infrastructure building (1997-2002)

The first stage of e-Learning development in Taiwan was led by the announcement of policy documents Building Infrastructure of eLearning in Schools and Master Plan for School eLearning (Ministry of Education (MOE) of Taiwan 1997, 2001). In this six-year stage, the Taiwan government made initiatives in three major aspects. 
First, ICT infrastructure of every school was established by building campus network of Internet connectivity, setting up personal computer laboratories, and equipping every classroom with a desktop computer connecting to the Internet for teaching use. Second, online learning communities were launched for school education by collaborating with the local research community on the EduCity Project, which allowed students to interact with each other in a hierarchy of classes and schools, exemplifying the concept of online learning society (Chan et al. 2001). Having a user population of 1.5 million by 2004 when the project ended, EduCity was probably the largest online learning community in the world at that time (Chan 2010). This online learning community, which was transferred to the largest local telecommunication company in Taiwan to continue its operation induced a profound impact on the later development and dissemination of e-Learning in Taiwan. Third, the Future Classroom Project, consisting of the eSchoolBag subproject and the Mobile Learning subproject, was experimented in a number of schools in Taipei City. The eSchoolBag subproject (Chang and Sheu 2002; Liu et al. 2002), later being expanded as a MOE-based eSchoolBag program in a larger scale, experiments how students interact with each other and the teacher inside a classroom wherein every student was equipped with a wirelessly connected learning device, either a clicker or a tablet computer. Another subproject, the Mobile Learning subproject, studied how students learned outside classroom, such as the case that each student carried a portable and wirelessly connected computing device (e.g., personal digital assistant) for studying butterflies in school garden or doing bird watching outdoor in the countryside (Chen et al. 2002).

\section{Stage 2: National science and technology program on e-Learning research,} with a white paper for e-Learning (2003-2008)

The second stage of e-Learning development in Taiwan was guided by the 10-year National Science and Technology Program for eLearning starting from 2003 as well as the White Paper for eLearning issued in 2008. The 10-year National Science and Technology Program for e-Learning announced in 2003 drove further research and development on e-Learning (National Science Council of Taiwan 2003). Inspired by the innovations of the EduCity and the Future Classroom project, this national program was a cross-ministry endeavor involving MOE, Ministry of Economic Affairs, Labor Council, and some other ministries, besides the National Science Council. It provided sponsorship of several eLearning Research Centers for Excellence, and in turn further spurred the growth of e-Learning research community in Taiwan. This research community is expected to continue contributing to the development of policy and practice of e-Learning in Taiwan in the future. The White Paper for eLearning issued in 2008 had three major missions: students making use of IT to enhance their learning and living; teachers utilizing IT to raise the quality of teaching; and classroom environment providing digital opportunity equally for all teachers and students (Ministry of Education, Taiwan 2008). Indeed, these missions have been quite accurately describing the subsequent efforts of the Taiwan government on e-Learning. 
Stage 3: Task force on digital literacy and national programs on mobile learning and school-based e-Learning (2009-2014)

Building on the achievements made in the second stage of e-Learning development, the Taiwan government continued the third stage of e-Learning development between 2009 and 2014. This stage was signified by four efforts: addressing the development of $21 \mathrm{st}$ century skills, putting the digital literacy as an official curriculum component, and introducing the Mobile Learning Program.

First, for developing 21 st century skills, the local e-Learning research community explored how to transform learning in school education through the suitable use of digital technologies for developing students' competencies in meeting the new demands in the 21 st century. They believe that, with the support of digital technology, the ways of learning and teaching are changing, for example, more emphasis on self-learning and group learning rather than the traditional teacher's expository instruction, the process of learning and teaching will nurture students' 21st century skills. In particular, they identified the competencies L4C (sounds like Learning for Competencies), namely Lifelong learning habit, Complex problem solving, Collaboration and communication, Critical thinking, and Creativity and imagination, as a set of 21st Century core competencies (Chan 2013). They also recommended that the approaches of artificial intelligence for learning, computersupported collaborative learning, digital game-based learning, and mobile learning are the potential ways of using digital technologies to transform learning and teaching in school, as well as to nurture students' interest, motivation, passion, and other aspects of affect in learning.

Second, for having the digital literacy as an official curriculum component, the Digital Literacy Task Force was set up by the National Academy for Educational Research of Taiwan in 2013 (National Academy for Educational Research of Taiwan, Taiwan 2013). This task force, for the first time in history of Taiwan, aims to define digital literacy for all school grades, making it to become a type of literacy per se, as like as the one for individual disciplines such as Chinese and English languages, mathematics, science, art, and others. In particular, the task force develops the assessment framework for digital literacies for the 18-year-old students, who are in their last year of senior high schools.

Third, for advancing the use of mobile technology across school curricula, in 2013, the eSchoolBag program was renamed as the Mobile Learning Program and extended with tens of schools for participation. This on-going program adopts the bottom-up approach to school-based research and development of potential mobile learning strategies. Most principals of the schools participated in this program are innovators of adopting technology in their schools, and they can, with considerable freedom, choose what they want to do for their school-based mobile learning projects.

Fourth, for supporting systematic or sustainable teacher professional development, the Taiwan government started to plan for teacher professional development programs to motivate teachers to change their pedagogical concept and teaching habit related to ICT integration into daily instruction, especially for the e-Learning pedagogies in the era of student-centered one-to-one classrooms (Chan et al. 2006). 
It can be said that the efforts made at this stage were urged by the stronger recognition of the value of transforming the teacher-centered classrooms that addressed expository instruction, to student-centered classrooms that addressed personalized learning and collaborative learning. In a way, these efforts have been preparing for, in 10 years or so, the emergence of more and more one-to-one classrooms as well as more and more novel pedagogies practiced in the seamless learning environment (Chan et al. 2006).

\section{Beijing}

The Beijing government has promoted the integration of ICT into learning and teaching in K-12 schools since the late 1990s, with the expectation that ICT can transform school education and facilitate student learning. In 2000, China's Ministry of Education held a historic meeting on e-Learning for school education with two important decisions: implementing Campus Network Construction Project for enhancing ICT infrastructure in schools and offering ICT-related curriculum for K-12 students and speeding up the integration of ICT into school curricula. The results of this historic meeting have guided the Beijing Municipal Commission of Education to plan for its strategies and policies on e-Learning across the three "Five-Year" plans on educational reform and development in 2000s. With the huge investment since 2001, the Beijing government has supported all levels of schools to gradually build up e-Learning environments by three stages as divided by the three "Five-Year" plans.

\section{Stage 1: The 10th five-year Beijing municipal plan of educational reform} and development (2001-2005)

In 2001, the Beijing government issued the policy document entitled "The 10th Five-Year Beijing Municipal Plan of Educational Reform and Development (20012005)" (Beijing Municipal Commission of Education 2001c), which started the first stage of e-Learning promotion in Beijing in 2000s. At this stage, the Beijing government envisioned that the key for students gaining success in the knowledge society was (1) to enable students get access Internet; (2) to develop students' attitude and capability for independent and lifelong learning; and (3) to develop students' ICT competency (Luo 2013). In this regard, the Beijing government further announced two other strategic documents. The first one was "Implementation on Campus Network Construction in Beijing K-12 Schools” with three steps (Beijing Municipal Commission of Education 2001b). Firstly, it required all primary and secondary schools in the city to get access to the Internet, and all of the county and urban areas must build up regional education hub and connect to Beijing Distance Educational Network (BDEN). Secondly, it required all of secondary schools, most of primary schools in urban area and part of primary schools in towns to build up campus network before the end of 2003. Thirdly, it required all primary and secondary schools to build up high-level campus network, with all classrooms having networked computers and being connected to each other. High levels of Education Resource Centre were also set up. 
The second one was "Announcement on Initiating Compulsory Course of Information Technology in Beijing K-12 Schools" with three focuses (Beijing Municipal Commission of Education 2001a). Firstly, the Beijing government put efforts in offering ICT-related curriculum in school education. It made ICT course become compulsory for high school students from the fall of 2001, and required primary schools in the city to offer ICT curriculum from the fall of 2003; students at three grades in primary school, one grade in senior school, and one grade in junior school were in turn need to take ICT course. Secondly, the Beijing government put efforts to promote ICT integration into curriculum delivery. It established effective e-Learning environment for encouraging teachers and students to use ICT in the learning and teaching processes. Thirdly, the Beijing government put efforts to provide ICT-related training for teachers. It trained ICT subject teachers with a scope on expertise knowledge and skills for ICT curriculum delivery, as well as trained teachers of other subjects with a scope on general knowledge and skills for the flexible use of ICT in subject teaching.

\section{Stage 2: The 11th five-year Beijing municipal plan of educational reform} and development (2006-2010)

At the final implementation stage of the "10th Five-Year Plan," the Beijing government noticed that local schools had developed a relatively strong foundation of ICT infrastructure, and most of the teachers had developed a habit of using ICT in their daily instruction. In 2006, the Beijing government announced the policy document "The 11th Five-Year Beijing Municipal Plan of Educational Reform and Development (2006-2010)” (Beijing Municipal Commission of Education 2006). This started the second stage of e-Learning promotion in Beijing, which included seven actions within three major focuses. First, the Beijing government put efforts in strengthening ICT integration into curriculum. Teachers are encouraged to extend the pedagogical use of ICT in classroom learning activities, in order to update students' learning ways from the traditional ones to the digital ones. Second, the Beijing government put efforts in enriching e-Learning pedagogy for curriculum delivery. Regular professional development activities and seminars are organized to enhance teachers' ability to apply ICT in their instruction. Third, the Beijing government engaged in establishing digital platforms for e-Learning in school education. It built data systems for the Beijing education information network to connect all the urban schools and rural schools in the city, and also a multimediasupported distance learning system, an online teaching platform, and an educational information management platform (Luo 2013).

\section{Stage 3: The 12th five-year Beijing municipal plan of educational reform} and development (2011-2015)

At the final implementation stage of the "11th Five-Year Plan," the Beijing government noticed that new emerging technologies became a powerful driving force for future learning in both formal and informal learning settings. Therefore, the policy document "The 12th Five-Year Beijing Municipal Plan of Educational 
Reform and Development (2011-2015)" was announced in 2011 (Beijing Municipal Commission of Education 2011) and the strategic plan "Three-Year Development Plan of Primary and Secondary Schools in Beijing (2012-2014)" was announced in 2012 (Beijing Municipal Government 2012). This guided the third stage of e-Learning promotion in Beijing, which included six actions with four major focuses. First, the Beijing government has put efforts in promoting mobile learning in school curricula. The major initiatives include establishing online Beijing Digital School and building an interaction platform for teachers to share their teaching experience in a wider range (Dong et al. 2013). Second, the Beijing government has put efforts in enhancing the development, provision, and sharing of digital resources for learning and teaching. The major initiatives include constructing high-quality digital educational resources; developing synchronized curriculum resources through professional teachers' teams; establishing a new mechanism for an efficient allocation of resources; and providing a variety of transmission channels and application modes for teachers to share education resources. Third, the Beijing government has made technical investment for optimizing e-Learning. The major initiatives include upgrading the basic network to connect Beijing Education Information Network to each family; building 100 digital campus model schools; building educational electronic authentication system; building hierarchical data storage and disaster recovery center; and establishing a scientific and effective mechanism supporting e-Learning. The construction of the digital campus enhances the utilization of instruction, research, administration, school-family connection, etc. (Huang 2009). Fourth, the Beijing government has put efforts in enhancing school leadership on e-Learning. School leadership on e-Learning is distributed among different sources of leadership, including senior management (SM), middle management (MM) as well as teachers (Huang and Hu 2012). The major initiatives include improving the decision-making abilities of school leaders in e-Learning promotion; integrating education e-government system, education system, internal coordination office, government, and school innovation management model; and establishing data management and capital support platform for an organic integration of education data, a scientific management, and a dynamic monitoring of educational decision-making and crisis management with valid data.

\section{Discussion from five perspectives of e-Learning development in school education}

Based on the above review of e-Learning policy in school education in Singapore, Hong Kong, Taiwan, and Beijing, this section compares the past experience of e-Learning in school education among the four Asian cities/regions. Table 2 summarizes the past policies on e-Learning in school education in Singapore, Hong Kong, Taiwan, and Beijing. 


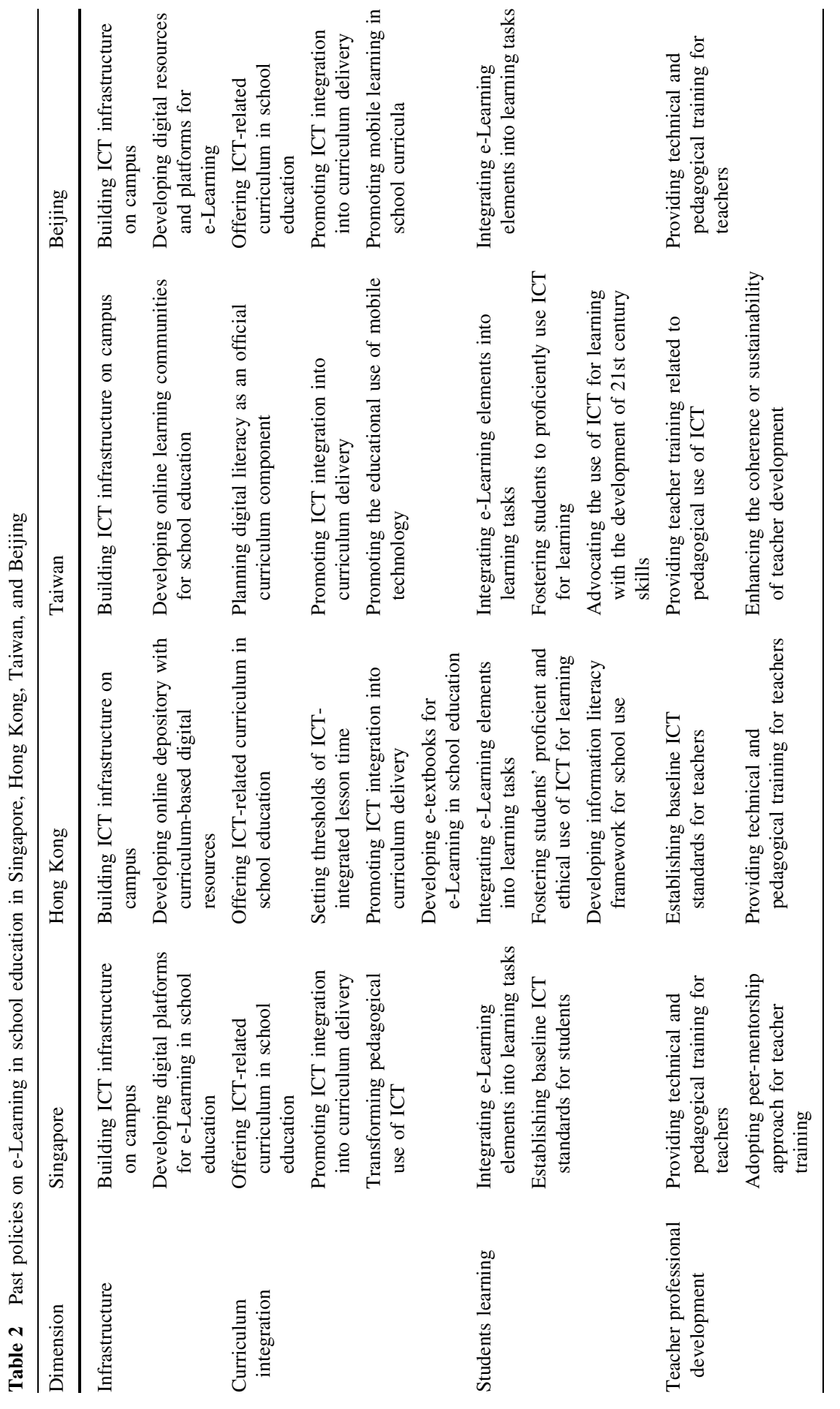




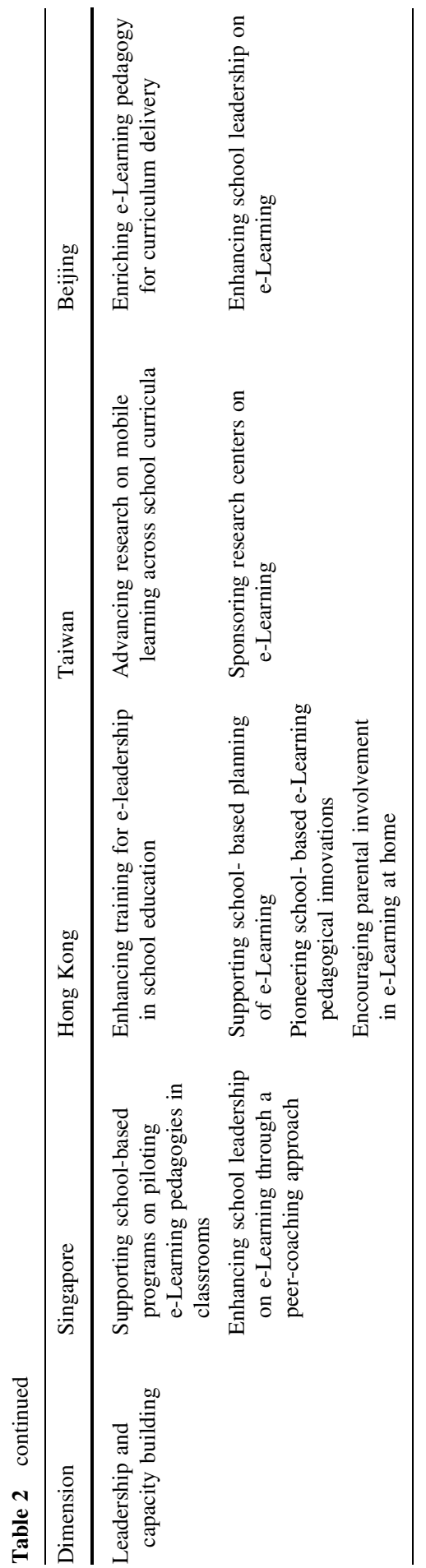




\section{Infrastructure}

The e-Learning policies on the dimension of infrastructure over the recent two decades have a change in focuses from basic infrastructure to digital resources and then to digital platforms for e-Learning. At the first stage, all the four cities/regions had a main focus on the readiness of computing hardware and Internet connectivity on campus. The related policy initiatives focused on supporting schools to build computer rooms/laboratories on campus, install campus-wide network for Internet connection, and acquire desktop computers for general classrooms. At the second stage, the four cities/regions had a continuous focus on maintaining ICT infrastructure on campus. There was an increasing attention to the digital resources for e-Learning purposes, as the efforts made by the Beijing government in establishing Beijing Digital School with digital resources for e-Learning in school education. There was also an initial work on promoting students' online community for e-Learning purposes, as the efforts made by the Taiwan government in the EduCity project since 2000. At the third stage, the focus was shifted to the readiness of computing hardware and Internet connectivity at home. The Singapore government set clear targets on students' rates of home computer ownership and home Internet connection. The Beijing government also highlighted their concern on ensuring students' home Internet connection for e-Learning after class. There was also a growing concern on the need to advance supporting systems for e-Learning. For example, the Beijing government put considerable efforts to build various types of electronic systems that support schools and teachers to systematically handle students' data on e-Learning processes. The Hong Kong government also put efforts to develop an online depository and a series of e-textbooks for supporting students and teachers to conveniently retrieve and share useful digital resources for e-Learning. The above summary reveals the trend toward the development of digital systems or platforms that can support students and teachers on an integral retrieval of learning data on e-Learning process.

\section{Curriculum integration}

The e-Learning policies on the dimension of curriculum integration over the recent two decades have a change in the focuses from teachers' instructional practices to student-centered learning paradigm and then to students' learning process using mobile technology. At the first stage, there were official inputs in setting teaching thresholds and offering ICT-related curriculum. For the former type of official inputs, the Hong Kong government requested teachers to meet the minimum competency level of teaching with ICT, and arrange at least $25 \%$ of their teaching time involving the use of ICT. For the latter type of official inputs, the government of Singapore, Hong Kong, and Beijing requested schools to provide ICT-related subjects for students in primary and secondary schools. At the second stage, there was an emerging consideration of paradigm shift to student-centered learning through e-Learning delivery. The governments of all the four cities/regions also highlighted this issue in their e-Learning policy documents at that time. At the third stage, there was a growing concern on the approach of mobile learning with learning 
platforms and quality e-resources/e-textbooks. The governments of Beijing and Taiwan planned for actions to integrate the use of mobile technology in day-to-day learning and teaching across different subjects in school education. Besides, there was also a growing concern on the development of 21st century skills in e-Learning. The governments of Singapore, Hong Kong, and Taiwan explicitly made the development of 21 st century skills as one of the major goals of learning in school education. The above summary reveals that future e-Learning should be a studentcentered learning process which is supported by mobile technology and targeted on enabling students to develop 21 st century skills through curriculum integration and delivery.

\section{Students learning}

The e-Learning policies on the dimension of students learning over the recent two decades have a change in the focuses from teachers' e-Learning integration into learning tasks to students' capacity building in e-Learning process. At the first stage, all the four cities/regions had a main focus on integrating e-Learning elements into learning tasks. This was kept at the second stage, in which the governments of Taiwan and Hong Kong put further efforts to prepare students to use ICT proficiently and ethically. The Taiwan government encouraged schools to engage students in the regular use of ICT in various day-to-day learning tasks, while the Hong Kong government developed an information literacy framework for guiding local teachers to empower students with the necessary knowledge and proper attitudes for information processing. At the third stage, there were increased efforts on ensuring students' proficient and ethical use of ICT. The Singapore government focused on ensuring students use ICT proficiently, through the establishment of baseline ICT standards for students together with the corresponding assessment tools for teacher use. The governments of Taiwan and Hong Kong worked further on ensuring students to use ICT proficiently and ethically, through the emphasis on information literacy/digital literacy in official curricula for school education. The above summary reveals the trend toward the empowerment of students in the proficient and ethical use of ICT for daily pursuits, especially for day-to-day learning.

\section{Teacher professional development}

The e-Learning policies on the dimension of teacher professional development over the recent two decades have an expansion of focuses from skills-oriented training to peer-supported sharing. At the first and second stages, all the four cities/regions focused on providing teachers with technical and pedagogical training. The training events were mainly organized in the form of workshop or seminar. Their contents mainly covered the hands-on practice of technical operation of digital tools and/or resources for learning and teaching, as well as the theoretical introduction of pedagogical issues in ICT integration for learning and teaching. At the third stage, there was a growing attention to the sustainability and scalability of teacher professional development on e-Learning. The Taiwan government concerned the 
cohesiveness of teacher professional development programs on e-Learning; with an expectation that teachers are enabled to regularly practice and refine pedagogical concept and teaching habit related to ICT integration into daily instruction. The Singaporean approach for teacher professional development has evolved as the ICT Masterplans for Education matures. Essentially, a more grounded and direct support structure emerges as the needs of teachers increase in complexity and diversity. Under mp3, this is done by allowing teachers to receive relevant and responsive pedagogical support from the selected peers "ICT Mentors" in the same schools through in-depth discussions about pedagogical use of ICT. The above summary reveals the trend toward the provision of coherent professional development fostering peer support within the teacher community.

\section{Leadership and capacity building}

The e-Learning policies on the dimension of leadership and capacity building over the recent two decades have an expansion of focuses from government-supported research to peer-supported training, school-based inputs, and parental involvement. At the first and second stages, efforts were made in government-supported research on e-Learning. The governments of all the four cities/regions provided schools with funding supports on conducting e-Learning research for piloting innovative ICTsupported pedagogies. For example, the Singapore government launched a series of pilot research on the use of technologies for teaching and learning in formal and informal environments, with the "early-adopters" schools experimented ICTenriched pedagogies in a wide array of subject domains across different school levels. The Taiwan government also supported schools on experimenting e-Learning pedagogies in the real classroom environment, with a focus on extending the use of mobile technology for learning and teaching across school curricula. There were also initial efforts in the community involvement in e-Learning. The Hong Kong government, for example, encouraged supports from community groups, tertiary institutions, and parents for the provision of ICT facilities, digital resources, and learning guidance for students' e-Learning after school. At the third stage, there was a growing emphasis on peer-supported training, school-based inputs, and parental involvement in e-Learning development. As for the peer-supported training, efforts were made by the Singapore government in enhancing school leadership on e-Learning through the online professional development program for school leaders under a peer-coaching approach. For the school-based inputs, efforts were made by the Hong Kong government in two ways: promoting school-based planning of ICT in education through the provision of relevant resource pack and planning tool, as well as piloting school-based e-Learning pedagogical innovations through the launch of territory-wide e-Learning school pilot scheme. As for the parental involvement, efforts were made by the Hong Kong government in providing parents with ICT-related programs on parental guidance on home use of ICT for learning, in order to raise their information literacy and assist them in guiding children's e-Learning at home. The above summary reveals the trend toward the concerted inputs from both schools and parents on supporting students to coherently use ICT for learning inside and outside of school. 


\section{Implications to future policy planning for e-Learning in school education}

E-Learning in future has the goal of supporting schools on realizing the process that is geared to student-centered development of both domain knowledge and 21st century skills and cultivating students who are able to proficiently and ethically use ICT for day-to-day learning. Building on the past experiences and the future needs of e-Learning in school education among the four Asian cities/regions, this section discusses five implications related to future policy planning for e-Learning.

The first implication is related to the provision of ICT infrastructure for e-Learning on campus. As mentioned, future e-Learning will emphasize a studentcentered learning process which is supported by mobile technology and targeted on enabling students to develop both domain knowledge and 21st century skills. This implies that schools need to be supported on creating e-Learning environments that make use of mobile technology to facilitate students to enhance 21st century skills through domain knowledge learning. Official policy initiatives on the creation of one-to-one digital classrooms are one of the promising directions in this aspect. In fact, the major Asian cities/regions have attempted to make the related future policy planning, in particular, the governments of Taiwan and Hong Kong (Chan 2013; Education Bureau 2014). The governments of Taiwan and Hong Kong both focus its related initiatives on the issue of wireless networking. In Taiwan, the government pledges to support schools to build campus-wide wireless coverage with considerable increase of network bandwidth, and in turn create digital classrooms for e-Learning with the support of mobile and wireless technology. In Hong Kong, the government pledges to support public sector schools to incrementally build the necessary WiFi infrastructure to cover all classrooms by phases within next three school years (Education Bureau 2014).

The second implication is related to the development of digital resources and e-textbooks for e-Learning. The learning process inside of digital classrooms exposes students to an extensive use of digital resources and e-textbooks for subject learning. This implies that schools need to be supported on the easy and systematic retrieval and sharing of suitable and sufficient digital resources and e-textbooks for e-Learning across school curricula. Official policy initiatives on the development of curriculum-based e-Learning resources and e-Learning platforms are, therefore, expected by the school education sector. In fact, the major Asian cities/regions have attempted to make the related future policy planning, in particular, the governments of Hong Kong and Beijing (Education Bureau 2014). In Hong Kong, the government pledges to expand, enrich, and update the free learning and teaching resources, packages, and e-textbooks on the existing governmental one-stop portal for the school education sector, as well as to develop an interoperable online integration services platform for the sharing of e-Learning resources and the access to e-Learning data among teachers and students. In Beijing, the government pledges to develop an online curriculum for school education, in which a series of e-textbooks fitting the local school curricula and online systems for pedagogical and administrative purposes will be constructed to support students, teachers, and parents on an integral retrieval of learning materials and learning data in e-Learning process. 
The third implication is related to the focus of student learning under e-Learning. The learning goal of future e-Learning is to empower students to the proficient and ethical use of ICT in daily life. This implies that schools need to be supported on the cultivation of students' 21 st century skills through daily curriculum delivery. In fact, the major Asian cities/regions have attempted to make the related future policy planning, in particular, the governments of Singapore and Taiwan. Both of the governments of Singapore and Taiwan emphasize the promotion of paradigm shift to student-centered learning in the school education sector, and value the role of ICT in realizing the student-centered learning process that engages students in the development and application of 21 st century skills. The Taiwan government even prepares to make digital literacy as an official component in school curricula.

The fourth implication is related to the provision of teacher professional development on e-Learning. As mentioned, there is a trend toward the provision of peer-supported professional development on e-Learning for teachers on a sustainable and scalable manner. This implies that schools need to be supported on organizing peer-supported professional development activities for teachers to sustainably enhance their e-Learning pedagogies. Official policy initiatives on the promotion of teachers' community of practice $(\mathrm{CoP})$ on e-Learning are, therefore, expected by the school education sector. In fact, the major Asian cities/regions have attempted to make the related future policy planning, in particular the governments of Hong Kong and Singapore (Education Bureau 2014; Ministry of Education, Singapore 2008). In Hong Kong, the government pledges to foster teachers' CoPs, both within and across schools, for mutual support on the planning and implementation of e-Learning, on top of the organization of a series of professional development programs on e-Learning at the generic teaching level as well as at the subject-specific levels. In Singapore, the government pledges to strengthen the scale-up of the use of ICT for teaching and learning through the "ideas to practice" framework and school-based approach within the teacher community across the country.

The fifth implication is related to the school leadership and capacity building for e-Learning. The desirable e-Learning process emphasizes not only the formal learning initiated in digital classrooms on campus but also the extended learning in which students continue peer discussions on the online platforms supported by mobile technology after class. This implies that schools need parental supports on procuring mobile devices for students' learning use, and creating home learning environments that are seamless with the classroom learning environments in order to facilitate students to coherently develop domain knowledge and 21st century skills. In fact, the major Asian cities/regions have attempted to make the related future policy planning, in particular the governments of Singapore and Hong Kong (Education Bureau 2014; Ministry of Education, Singapore 2008). In Singapore, the government has put in place incentives to encourage homeowner of broadband connections and computers. In Hong Kong, the government pledges to continue encouraging parents to support students on the proficient, healthy, and ethical use of ICT for home learning, as well as on a better use of their own portable computing devices for school learning. 


\section{Conclusions and challenges}

This article reviews the e-Learning policy in school education in Singapore, Hong Kong, Taiwan, and Beijing in the recent two decades. The past experiences of these four major Asian cities/regions in the development of e-Learning policies are compared in terms of five dimensions, namely infrastructure, curriculum integration, students learning, teacher professional development, and leadership and capacity building. From the planning in Taiwan, e-Learning in school education should target at supporting students to develop both domain knowledge and 21st century skills. This educational goal requires the shift to student-centered paradigm in school education. From the planning in Hong Kong, the creation of one-to-one digital classrooms would be helpful in this regard. The learning process in one-toone digital classrooms requires students to extensively use digital resources and e-textbooks, as reflected by the planning in Beijing and Hong Kong. The learning environment which emphasizes the use of such e-Learning materials in one-to-one digital classrooms may be new to teachers. From the planning in Singapore, related teacher professional development on sustainable and scalable manner is therefore necessarily important. For the holistic realization of these e-Learning directions in future, official supports on school leadership and capacity building are required. These analysis results imply several challenging issues that policy makers should address in the future planning for e-Learning in school education.

In the dimension of infrastructure, schools might face challenges in ensuring every student to possess a personally owned portable computing device for classroom learning, despite the government supports on building campus-wide wireless network. Policy initiatives should then be made for supporting schools to mobilize parental inputs in hardware procurement for students.

In the dimension of curriculum integration, schools might face challenges in bridging students' gap in using ICT for formal learning in class and informal learning after school, as the government supports emphasize pedagogical advancement of ICT-supported classroom learning. Policy initiatives should then be made for supporting schools to engage students in the ICT-supported learning process inside and outside school coherently.

In the dimension of students learning, schools might face challenges in realizing the ultimate goal of e-Learning at developing students' capability of self-regulated learning, despite the government supports newly concern the 21st century skills development through e-Learning. Policy initiatives should then be made for supporting schools to re-interpret learning opportunities for students to develop and apply generic skills to self-regulate their learning process.

In the dimension of teacher professional development, schools might face challenges in enhancing teachers' capacity to truly realize student-centered learning in e-Learning environments, even the government supports newly shift emphasis on the pedagogical aspect instead of technical aspect on e-Learning. Policy initiatives should then be made for supporting teachers to master teaching models that facilitate their work on integrating student-centered learning elements into students' knowledge construction. 
In the dimension of leadership and capacity building, schools might face challenges in developing an e-Learning plan that holistically addresses every concern of different stakeholders in school, even the government supports emphasize the school-based planning of e-Learning development. Policy initiatives should then be made for empowering principals to build a common consent with the senior management team, curriculum coordinators, panel heads, subject teachers and parents, to the vision and direction of e-Learning plans in school.

\section{References}

Au, W. K., Kong, S. C., Leung, K. P., Ng, M. W., Pun, S. W. (2000). Information technology competency for Hong Kong teachers-A new era and a new paradigm. In Young, S., Greer, J., Maurer, H., Chee, Y. S. (Eds.), Proceedings of the International Conference on Computers in Education/International Conference on Computer-Assisted Instruction 2000, Vol. 2 (pp. 1028-1036). Taipei, Taiwan: National Tsing Hua University.

Beijing Municipal Commission of Education. (2001a). Announcement on initiating compulsory course of information technology in Beijing K-12 schools. Beijing: Beijing Municipal Commission of Education.

Beijing Municipal Commission of Education. (2001b). Implementation on campus network construction in Beijing K-12 schools. Beijing: Beijing Municipal Commission of Education.

Beijing Municipal Commission of Education. (2001c). The 10th five-year Beijing municipal plan of educational reform and development (2001-2005). Beijing: Beijing Municipal Commission of Education.

Beijing Municipal Commission of Education. (2006). The 11th five-year Beijing municipal plan of educational reform and development (2006-2010). Beijing: Beijing Municipal Commission of Education.

Beijing Municipal Commission of Education. (2011). The 12th five-year Beijing municipal plan of educational reform and development (2011-2015). Beijing: Beijing Municipal Commission of Education.

Beijing Municipal Government. (2012). Three-year development plan of primary and secondary schools in Beijing (2012-2014). Beijing: Beijing Municipal Government.

Borokhovski, E., Bernard, R. M., Mills, E., et al. (2011). An extended systematic review of Canadian policy documents on e-Learning: What we're doing and not doing. Canadian Journal of Learning and Technology, 37(3), 30.

Chan, T. W. (2010). How East Asian classrooms may change over the next 20 years. Journal of Computer Assisted learning, 26(1), 28-52.

Chan, T. W. (2013). L4C: 21st century core competencies and school transformation through digital learning. Global Chinese Journal on Computers in Education, 8(1, 2), 169-183. In Chinese.

Chan, T. W., Hue, C. W., Chou, C. Y., \& Tzeng, O. J. L. (2001). Four spaces of network learning models. Computer \& Education, 37, 141-161.

Chan, T. W., Roschelle, J., Hsi, S., Kinshuk, S. M., Brown, T., Patton, C., et al. (2006). One-to-one technology-enhanced learning: An opportunity for global research collaboration. Research and Practice in Technology Enhanced Learning, 1(1), 3-29.

Chang, C., \& Sheu, J. (2002). Design and implementation of ad hoc classroom and eSchoolBag system for ubiquitous learning. In M. Milrad, U. Hoppe \& Kinshuk (Eds.), Proceedings of the IEEE International Workshop on Wireless and Mobile Technologies in Education (pp. 8-14). Los Alamitos, USA: IEEE Computer Society.

Chen, Y., Kao, T., Sheu, J., Chiang, C. (2002). A mobile scaffolding-aid-based bird-watching learning system. In Milrad, M., Hoppe, U., Kinshuk (Eds.), Proceedings of the IEEE International Workshop on Wireless and Mobile Technologies in Education (pp. 15-22). Los Alamitos, USA: IEEE Computer Society.

Chen, W., \& Looi, C.-K. (2011). Active classroom participation in a Group Scribbles primary science classroom. British Journal of Educational Technology, 42(2), 676-686. 
Condie, R., Munro, B. (2007). The impact of ICT in schools: A landscape review. Becta Research. Retrieved June 12, 2014, from http://www.teindia.nic.in/e9-tm/Files/ICT_Documents/ImpactICT_ Becta.pdf.

Curriculum Development Council. (2001). Learning to learn-The way forward in curriculum development. Hong Kong: Curriculum Development Council.

Dong, J., Guo, G. Z., \& Li, X. P. (2013). Beijing Digital School enables smart learning. China Education Info, 10, 15-18. (In Chinese).

Education Bureau. (2008). Right technology at the right time for the right task. Hong Kong: Education Bureau.

Education and Manpower Bureau. (1998). Information technology for learning in a new era: Five-year strategy-1998/99-2002/03. Hong Kong: Education and Manpower Bureau.

Education and Manpower Bureau. (2004). Empowering learning and teaching with information technology. Hong Kong: Education and Manpower Bureau.

Education and Manpower Bureau. (2005a). Information literacy framework for Hong Kong: Building the capacity of learning to learn in the information age. Hong Kong: Education and Manpower Bureau.

Education and Manpower Bureau. (2005b). Overall study on reviewing the progress and evaluating the Information Technology in Education (ITEd) projects 1998/2003. Hong Kong: Education and Manpower Bureau.

Education and Manpower Bureau. (2007). Phase (I) study on evaluating the effectiveness of the 'Empowering Learning and Teaching with Information Technology' strategy (2004/2007). Hong Kong: Education and Manpower Bureau.

Education Bureau. (2009a). "School Development of IT in Education” Resource Pack. Retrieved June 12, 2014, from http://edbsdited.fwg.hk/eng/resourcepack.php.

Education Bureau. (2009). Working group on textbooks and e-Learning resources development-main report. Hong Kong: Education Bureau.

Education Bureau. (2012). Review surveys of the third strategy on information technology in education. Hong Kong: Education Bureau.

Education Bureau. (2014). Realising IT potential, Unleashing learning power: A holistic approach. Hong Kong: Education Bureau.

Erichsen, E. R., \& Salajan, F. D. (2014). A comparative analysis of e-learning policy formulation in the European Union and the United States: Discursive convergence and divergence. Comparative Education Review, 58(1), 135-165.

Flanagan, L., \& Jacobsen, M. (2003). Technology leadership for the twenty-first century principal. Journal of Educational Administration, 41(2), 124-142.

Gülbahar, Y. (2007). Technology planning: A roadmap to successful technology integration in schools. Computers \& Education, 49(4), 943-956.

Gut, D. M. (2011). Integrating 21st century skills into the curriculum. In G. Wan \& D. M. Gut (Eds.), Bringing schools into the 21st Century (pp. 137-157). Dordrecht; New York: Springer.

Hoffman, J. (2010). What we can learn from the first digital generation: Implications for developing twenty-first century learning and thinking skills in the primary grades. Education 3-13, 38(1), 47-54.

Huang, R. H. (2009). What digital campus should focus on? Beijing Education, 8, 6-7.

Huang, R. H., \& Hu, Y. B. (2012). ICT leadership and construction of ICT in elementary and secondary schools. Open Education Research, 18(5), 11-17.

Info-communications Development Authority of Singapore (iDA). (2003). Infocomm21 and Connected Singapore reports from the Infocomm Development Authority (iDA). Retrieved June 12, 2014, from http://www.ida.gov.sg/About-Us/Corporate-Publications/Past-Infocomm-Plans.

Info-communications Development Authority of Singapore (iDA). (undated). Intelligent Nation 2015 plans and reports from the Infocomm Development Authority (iDA). Retrieved June 12, 2014, from http://www.ida.gov.sg/Infocomm-Landscape/iN2015-Masterplan.

Kong, S. C. (2007). The development and validation of an information literacy model for Hong Kong students: Key issues in the professional development of teachers for capacity building. Technology, Pedagogy and Education, 16(1), 57-75.

Kong, S. C. (2008). A curriculum framework for implementing information technology in school education for fostering information literacy. Computers \& Education, 51(1), 129-141.

Kong, S. C. (2009). An empirical study on school-based planning for technology enhanced learning in the twenty-first century. Technology, Pedagogy and Education, 18(3), 343-359. 
Kong, S. C., Chan, T.-W., Griffin, P., Hoppe, U., Huang, R., Kinshuk, L. C. K., et al. (2014). E-learning in school education in the coming 10 years for developing 21st century skills: Critical research issues and policy implications. Educational Technology and Society, 17(1), 70-78.

Law, N., Pelgrum, W. J., Plomp, T. (2008). Pedagogy and ICT use: In schools around the world: Findings from the IEA SITES 2006 study. New York: Springer; Hong Kong: Comparative Education Research Centre, the University of Hong Kong.

Liu, T., Wang, H., Liang, J., Chan, T. W., Yang, J. (2002). Applying wireless technologies to build a highly interactive learning environment. In M. Milrad, U. Hoppe \& Kinshuk (Eds.), Proceedings of the IEEE International Workshop on Wireless and Mobile Technologies in Education (pp. 15-22). Los Alamitos, USA: IEEE Computer Society.

Luo, J. (2013). Building public service systems for elementary education through educational cloud. $e$ Education Research, 6, 58-63. (In Chinese).

Ministry of Education, Singapore. (1997). 1st ICT Masterplan for Education (mp1) from Ministry of Education Singapore. Retrieved June 12, 2014, from http://ictconnection.moe.edu.sg/our-ictmasterplan-journey/masterplan-1.

Ministry of Education, Singapore. (2003a). 2nd ICT Masterplan for Education (mp2) from Ministry of Education Singapore. Retrieved June 12, 2014, from http://ictconnection.moe.edu.sg/our-ictmasterplan-journey/masterplan-2.

Ministry of Education, Singapore. (2003b). Education statistics digest 2003. Singapore: Ministry of Education, Singapore.

Ministry of Education, Singapore. (2008). 3rd Masterplan for ICT in Education. Retrieved June 12, 2014, from http://ictconnection.moe.edu.sg/cos/o.x?c=/ictconnection/pagetree $\&$ func $=$ view $\&$ rid $=665$.

Ministry of Education, Taiwan. (1997). Building infrastructure of eLearning in schools. Taipei: Ministry of Education, Taiwan.

Ministry of Education, Taiwan. (2001). Master plan for school eLearning. Taipei: Ministry of Education, Taiwan.

Ministry of Education, Taiwan. (2008). White paper for eLearning. Taipei: Ministry of Education, Taiwan.

National Academy for Educational Research of Taiwan, Taiwan. (2013). Final report of 12-Year Basic Education Implementation Plan-Project on Improving National Literacy. Retrieved 12 June 2014, from http://literacytw.naer.edu.tw/data/cht/20140430/20140430v0x2d6.pdf.

National Science Council, Taiwan. (2003). National Science and Technology Program for eLearning. Taipei: National Science Council, Taiwan.

Pun, S. W., Kong, S. C, \& Au, W. K. (2000). Information technology competencies: What teachers want to know and be able to do. In G. K. Yeo (Ed.), Proceedings of the Fourth Global Chinese Conference on Computers in Education, Vol. 1 (pp. 281-285). Singapore: Global Chinese Conference on Computers in Education.

Rotherham, A. J., \& Willingham, D. (2009). 21st Century Skills: The challenges ahead. Educational Leadership, 67(1), 16-21.

Rowan, B., \& Miller, R. J. (2007). Organizational strategies for promoting instructional change: Implementation dynamics in schools working with comprehensive school reform providers. American Educational Research Journal, 44(2), 252-297.

Teo, C. H. (1997). 'Opening new frontiers in education with Information Technology (IT)'. Opening address delivered at the launch of the Masterplan for IT in Education, 28 April 1997. Suntec City, Singapore. Retrieved June 12, 2014, from http://www.moe.gov.sg/media/speeches/1997/280497. htm.

Vanderlinde, R., Dexter, S., \& van Braak, J. (2012). School-based ICT policy plans in primary education: Elements, typologies and underlying processes. British Journal of Educational Technology, 43(3), 505-519.

Whitehead, B. M., Jenson, D. F. N., \& Boschee, F. (2003). Planning for technology: A guide for school administrators, technology coordinators, and curriculum leaders. Thousand Oaks, CA: Corwin Press. 
Siu Cheng Kong is Professor and Head of Department of the Department of Mathematics and Information Technology and Director of Centre for Learning, Teaching and Technology at The Hong Kong Institute of Education. He is also the Convener of Theory and Practice of Pedagogical Design for Learning in Digital Classrooms International Research Network (IRN) under World Educational Research Association (WERA). His research interests include pedagogy in digital classroom; IT in mathematics education; information literacy education; and policy, practice, and research in technology transformed education.

Tak-Wai Chan is Chair Professor of Graduate Institute of Network Learning Technology in National Central University, Taiwan. He has been involving various research topics, including game-based learning, mobile learning, one-to-one technology enhanced learning, network learning community, seamless learning, computer supported collaborative learning, and artificial intelligence in education. More recently, he is interested in interest-driven and creation-based learning for mathematics and language.

Ronghuai Huang is a professor of School of Educational Technology at Beijing Normal University and Deputy director of Collaborative \& Innovative Center for Educational Technology jointly launched by Beijing Normal University and Central China Normal University. His research interests include smart learning environment, e-textbooks, and computer-supported collaborative learning. He has been involved in many research projects and published many papers in educational technology journals.

Horn Mun Cheah obtained his BA, MPhil and PhD in Physics from University of Cambridge, UK. His current research interests include the use of technologies in teaching and learning, 21st Century skills assessment practices, and adult education. He was the former Dean for Foundation Programmes, overseeing all initial teacher education programmes at the National Institute of Education, Singapore; and followed by a stint as Director, Educational Technology Division at the Ministry of Education. He is presently the Assistant Provost at SIM University, Singapore. 